\title{
Sodium alginate from Sargassum wightii retards mortalities in Penaeus monodon postlarvae challenged with white spot syndrome virus
}

\author{
Grasian Immanuel*, Madasasmy Sivagnanavelmurugan, \\ Varatharajan Balasubramanian, Arunachalam Palavesam
} Marine Biotechnology Division, Centre for Marine Science and Technology Manonmaniam Sundaranar University,
Rajakkamangalam-629502, Kanyakumari District, Tamilnadu, India

\begin{abstract}
Sodium alginate extracted from brown seaweed Sargassum wightii $(16.35 \pm 1.42 \%$, mean $[ \pm \mathrm{SD}$ ] yield from 5 extractions) was prepared as a powder or beads and used to enrich Artemia nauplii at concentrations of 100, 200, 300 and $400 \mathrm{mg} \mathrm{l}^{-1}$. The alginate-enriched nauplii were fed to Penaeus monodon shrimp postlarvae (PL) stage 15 (PL15, i.e. $15 \mathrm{~d}$ old) for $20 \mathrm{~d}$. Mean weight gain and specific growth rate over this period were $0.24 \mathrm{~g}$ and $15.8 \%$, respectively, in PL groups not fed alginate, and $0.20-0.28 \mathrm{~g}$ and $14.7-16.5 \%$, respectively, in PL groups fed alginate. Amongst PL35 then challenged with white spot syndrome virus (WSSV) by immersion, all PL not fed alginate died within $9 \mathrm{~d}$. However, amongst PL fed the 4 concentrations of alginate powder or beads, mortality rates reduced with increasing alginate concentration, and between 25 and $32 \%$ PL remained alive when the bioassay was terminated on Day 21. Amongst alginate-fed PL groups compared with the control group, mortality was reduced by 26.5 to $58.4 \%$. Nested PCR detection of WSSV revealed sodium alginate concentration-dependent reductions in infection loads. The data indicate that sodium alginate extracted from brown seaweed and fed to P. monodon can retard progression of WSSV disease.
\end{abstract}

KEY WORDS: Tiger shrimp $\cdot$ WSSV $\cdot$ Brown seaweed $\cdot$ Algal extract $\cdot$ Microbeads $\cdot$ Viral disease $\cdot$ PCR

\section{INTRODUCTION}

Aquaculture of the major shrimp species, including giant tiger shrimp Penaeus monodon, Kuruma shrimp Marsuspenaeus japonicus and Pacific white shrimp Litopenaeus vannamei, has suffered in many countries owing to disease caused by viruses such as white spot syndrome virus (WSSV) (Chou et al. 1995), yellow head virus (YHV) (Wang \& Chang 2000), Taura syndrome virus (TSV) (Tu et al. 1999) and monodon baculovirus (MBV) (Lightner et al. 1987). However, by far the most widespread and devastating disease problems in shrimp have been caused by
WSSV (Moscardi 1999). The principal gross signs of white spot disease (WSD) are the development of white spots on the shrimp exoskeleton and carapace, rapid reductions in feed consumption, lethargy and reddening of appendages; the disease can result in $100 \%$ mortality of pond stocks within 3 to $10 \mathrm{~d}$ of the disease becoming evident (Flegel 1997).

The serious worldwide impacts of WSD and the broad host range of WSSV have prompted efforts to develop disease control strategies based on environmental management, quarantine procedures and immunostimulants as well as virus neutralization and immunization (Xiang 2001). Protective effects 
against WSSV infection have been reported for peptidoglycan- and lipopolysaccharide-based immunostimulants (Itami et al. 1998, Takahashi et al. 2000) and $\beta$-1,3-glucan (Song et al. 1997, Chang et al. 1999) delivered orally to Marsuspenaeus japonicus and Penaeus monodon. Protective responses against WSD have also been reported via oral delivery of herbal immunostimulants, such as an extract from Cynodon dactylon plants (Citarasu et al. 2006, Rameshthangam \& Ramasamy 2007, Balasubramanian et al. 2008), and an acyclic nucleoside phosphonate ([S]-1-3-hydroxy-2-phosphonyl methoxy propyl cytosine) supplemented with extracts of the marine blue-green algae Spirulina platensis (Rahman et al. 2006). More recently, Cereops tagal mangrove extracts have been screened for anti-WSSV activity in P. monodon (Sudheer et al. 2011), and Litopenaeus vannamei immersed in seawater containing Sargassum hemiphyllum var. chinensis powder showed increased protection against Vibrio alginolyticus and WSSV (Huynh et al. 2011).

Seaweeds are multicellular algae that can produce several substances found to have immunostimulatory activity, and brown seaweeds have recently been examined as a source of polysaccharides potentially useful as therapeutic agents and antibiotics. Fucoidan-containing extracts (Chotigeat et al. 2004) and hot water extracts (Immanuel et al. 2010) of Sargassum spp. provide Penaeus monodon with some resistance to WSD, as have fucoidan extracts from Cladosiphon okamuranus seaweed in Marsuspenaeus japonicus (Takahashi et al. 1998). Sodium alginate extracted from brown algae Undaria pinnatifida and Macrocystis pyrifera can enhance the nonspecific defense response of common carp Cyprinus carpio to Edwardsiella tarda (Fujiki et al. 1994, 1997). It can also enhance the migration of carp head kidney phagocytes to the peritoneal cavity to increase phagocytic activity (Fujiki \& Yano 1997) and can enhance the survival of juvenile turbot Scophthalmus maximus challenged with Vibrio anguillarum (Skjermo et al. 1995). Similarly, alginate extracted from brown algae $U$. pinnatifida and Lessonia nigrecans increase Litopenaeus vannamei resistance to $V$. alginolyticus (Cheng et al. 2004).

Studies of methods to improve shrimp resistance to viral disease include immersion, injection, bioencapsulation and oral delivery routes of immunostimulants. For example, live Artemia have been used as a bioencapsulation system for nutrients (Watanabe et al. 1983), antimicrobial agents (Dixon et al. 1995) and antigens (Campbell et al. 1993). To further examine the potential protective properties of seaweed poly- saccharides, we evaluated the ability of sodium alginate extracted from brown seaweed Sargassum wightii to protect Penaeus monodon postlarvae against WSD.

\section{MATERIALS AND METHODS}

\section{Sodium alginate extraction from seaweed}

Sargassum wightii seaweed was collected from coastal villages in the Kanyakumari District, Tamilnadu, India, washed thoroughly and dried under shade at room temperature. The dried seaweed was ground using a mixer grinder and nonpowdered material was removed by using a sieve (Immanuel et al. 2004). Sodium alginate was extracted from the ground seaweed by using a method modified from Torres et al. (2007). Briefly, $100 \mathrm{~g}$ of seaweed powder was soaked in $2 \%$ formaldehyde in an air-tight flask for $24 \mathrm{~h}$, the formaldehyde was filtered off and the solid residue was washed 2 to 3 times with distilled water. The residue was placed in $0.2 \mathrm{M} \mathrm{HCl}$ at room temperature for $24 \mathrm{~h}$, and the solid residue was again recovered by filtration and washed again 2 to 3 times in distilled water. The residue was extracted overnight in $2 \% \mathrm{Na}_{2} \mathrm{CO}_{3}$ and filtered through muslin cloth. The solution was bleached with $2.5 \%$ sodium hypochlorite and liquid was then evaporated off in an oven at $60^{\circ} \mathrm{C}$. The resulting residue was scraped from the container, made into a powder and weighed to calculate sodium alginate yield (\%) as (sodium alginate weight/milled seaweed weight) $\times 100$.

\section{Physicochemical properties of sodium alginate}

The colour, odour, taste and texture of extracted sodium alginate were evaluated using methodologies described previously (Kumar et al. 2011). A digital pH meter (Model 2001, Digisum Electronics System) was used to determine the $\mathrm{pH}$ of a $1 \%$ sodium alginate solution. Moisture content of the powder was determined using the Indian Standards Institution method (ISI 1984). Protein, carbohydrate, lipid, fucose and sulfate contents were estimated using standard methods (Seifter et al. 1950, Lowry et al. 1951, Dubois et al. 1956, Folch et al. 1957, Dodgson \& Price 1962). Ash content was determined by combusting $1 \mathrm{~g}$ sodium alginate powder in a silica crucible in a muffle furnace at $600^{\circ} \mathrm{C}$ and, once cooled, weighing the ash. Ash prepared as described was boiled in $25 \mathrm{ml}$ of $2 \mathrm{~N} \mathrm{HCl}$ for $5 \mathrm{~min}$, and any 
insoluble ash was collected on ash-free filter paper and washed with hot water. This insoluble ash was transferred into a silica crucible, combusted and weighed as described above. The procedure was repeated to get an average weight to accurately determine the percentage of acid-insoluble ash. Ash was boiled similarly in $25 \mathrm{ml}$ water for $5 \mathrm{~min}$, and insoluble ash was collected and washed as above, transferred to a silica crucible, combusted for $15 \mathrm{~min}$ and weighed. The procedure was repeated to get an average weight of water-insoluble matter that was subtracted from total ash weights to determine the percentage water-soluble ash.

\section{Preparation and Artemia enrichment of sodium alginate micro-beads}

Micro-beads containing sodium alginate were prepared as described previously (Skjermo et al. 1995). Briefly, $1 \mathrm{~g}$ sodium alginate powder dissolved in $100 \mathrm{ml}$ distilled water was sprayed through a nozzle $(45 \mu \mathrm{m})$ into an aqueous solution of $50 \mathrm{mM} \mathrm{CaCl}$ in $5 \%$ methanol, upon which beads formed instantly. Beads collected onto a sieve were washed gently in $500 \mathrm{ml}$ of $3 \mathrm{mM} \mathrm{CaCl}$ before being suspended in $200 \mathrm{ml}$ of $3 \mathrm{mM} \mathrm{CaCl} 2$. Bead diameters ranged from 10 to $35 \mu \mathrm{m}$. Before enrichment in Artemia, beads were washed in distilled water and collected by centrifugation at $1957 \times g$ for $5 \mathrm{~min}$.

Over a $12 \mathrm{~h}$ period, batches of Artemia franciscana nauplii (instar II stage) were fed (encapsulated) with either sodium alginate powder or beads at various concentrations of 100, 200, 300 and $400 \mathrm{mg} \mathrm{l}^{-1}$. Nauplii were stocked at a density of 20 individuals (ind.) $\mathrm{ml}^{-1}$ in glass containers containing $5 \mathrm{l}$ seawater that was aerated mildly to maintain oxygen levels and to disperse dietary particles uniformly. The encapsulated Artemia nauplii were collected in a sieve, washed carefully and stored. To assess whether alginate powder and beads had been encapsulated, some nauplii were examined under a microscope to confirm that their guts were full.

\section{Shrimp and alginate feeding regimen}

Penaeus monodon postlarvae (PL) stage 7 (PL7, i.e. 7 d old) were obtained from Matsyafed Hatchery, Quilon, Kerala. Upon arrival at the laboratory, PL were stocked into a $100 \mathrm{l}$ fiberglass tank filled with filtered natural seawater (32 $\pm 1 \mathrm{ppt})$ at room temperature $\left(27 \pm 1^{\circ} \mathrm{C}\right)$ and aerated to maintain dissolved oxygen levels at $>6 \mathrm{mg} \mathrm{l}^{-1}$. PL were acclimated for $8 \mathrm{~d}$ on a diet of live Artemia nauplii.

After measuring their length and weight, uniformly sized PL15 Penaeus monodon (10.8 \pm 3.6 mg, mean \pm $\mathrm{SD})$ were selected and stocked at a density of $10 \mathrm{ind}$. $\mathrm{l}^{-1}$ into small tanks containing $25 \mathrm{l}$ of mildly aerated, filtered seawater (salinity, $32 \pm 1$ ) at $28 \pm 1^{\circ} \mathrm{C}$. Postlarval groups were fed diets of control Artemia or Artemia enriched by feeding them either sodium alginate powder or beads at the concentrations described above. Artemia were provided ad libitum at $06: 00,14: 00$ and $18: 00 \mathrm{~h}$ at rates of 30,30 and $40 \%$ daily ration, respectively. Any uneaten Artemia nauplii were collected before each feeding and half the water was exchanged daily. To maintain the nutritional quality of Artemia over the $20 \mathrm{~d}$ feeding trial (PL15 to PL35), enriched Artemia preparations were maintained with gentle aeration at 4 to $10^{\circ} \mathrm{C}$ (Leger et al. 1983). Each diet was assessed in triplicate groups of PL. After feeding for $20 \mathrm{~d}$, PL weight gain was calculated for each group by deducting their initial weight from their final weight. The specific growth rate (SGR) over the period, expressed as percentage increase, was calculated by using the formula $\mathrm{SGR}=\left[\left(\ln W_{2}-\ln W_{1}\right) /\left(t_{2}-t_{1}\right)\right] \times 100$, where $W_{1}=$ initial weight at time $t_{1}$ and $W_{2}=$ final weight at time $t_{2}$.

\section{WSSV inoculum and challenge}

WSSV-infected Penaeus monodon with prominent exoskeleton spots were collected from local shrimp farms. Cephalothorax soft tissues including gills were homogenized and clarified by low-speed centrifugation at $3000 \times g$ for $20 \mathrm{~min}$ at $4^{\circ} \mathrm{C}$. The clarified supernatant was centrifuged again at $8000 \times g$ for $30 \mathrm{~min}$ at $4^{\circ} \mathrm{C}$, and the final supernatant was filtered through a $0.4 \mu \mathrm{m}$ membrane filter and stored at $-20^{\circ} \mathrm{C}$. The presence of WSSV in the inoculum was confirmed by nested PCR (Yoganandhan et al. 2003).

After feeding on the alginate diets, groups of PL35 Penaeus monodon $(242.1 \pm 28.0 \mathrm{mg})$ were challenged with WSSV by immersion. Each of the triplicate groups comprised $100 \mathrm{PL}$ stocked at a density of 10 ind. $\mathrm{l}^{-1}$ in a $15 \mathrm{l}$ plastic tank containing $10 \mathrm{l}$ sterilized, aerated seawater. Before use, air stones and tubes were sterilized by immersion in $2.6 \%$ sodium hypochlorite and washed thoroughly with sterilized tap water. Tanks were covered to prevent crossexposure and aseptic techniques were applied. The WSSV inoculum was added to the water at a dose of $1 \mathrm{ml} \mathrm{l}^{-1}$ (i.e. $0.1 \% \mathrm{v} / \mathrm{v}$ ) as recommended previously 
(Chen et al. 2000). During the challenge experiment, PL were fed with their respective control or alginateenriched Artemia nauplii diets.

Postlarval survival was monitored at $8 \mathrm{~h}$ intervals and PL not reacting to gentle mechanical stimulation with a small, soft paintbrush were considered to be dead and were removed. Mortality observed at each time point was used to calculate mortality per day, and all trials weres terminated on Day 21 postchallenge. A cumulative mortality index (CMI) of each group was calculated by using the formula: $\mathrm{CMI}=\mathrm{D} x_{1}+\mathrm{D} x_{2}+\mathrm{D} x_{3} \ldots+\mathrm{D} x_{n}$ (final day), where $\mathrm{D}=$ number of dead PL on each day $\left(x_{1}\right.$ to $\left.x_{n}\right)$. The higher the CMI value was, the lower the resistance was considered to be to WSSV. By using these CMI values, percentage reductions in mortality were calculated (Immanuel et al. 2001, 2004, 2007, 2010, 2012a).

\section{WSSV PCR}

WSSV loads in dead PL collected during the challenge trial were estimated by PCR. Dead PL preserved in $70 \%$ ethanol were rehydrated in distilled water for $1 \mathrm{~h}$ before DNA was extracted as described previously (Lo et al. 1996). Briefly, each $\mathrm{PL}$ was homogenized in NaCl-Tris-EDTA buffer (0.2 $\mathrm{M} \mathrm{NaCl}, 20 \mathrm{mM}$ Tris-HCl, $20 \mathrm{mM}$ EDTA, $\mathrm{pH}$ 7.4) and centrifuged at $3000 \times g$ at $4^{\circ} \mathrm{C}$. The supernatant was mixed with a digestion buffer (100 mM NaCl, 10 mM Tris- $\mathrm{HCl}, \mathrm{pH}$ 8.0, $50 \mathrm{mM}$ EDTA, pH 8.0, 0.5\% sodium dodecyl sulphate, $0.1 \mathrm{mg} \mathrm{ml}^{-1}$ Proteinase $\mathrm{K}$ ) and incubated at $65^{\circ} \mathrm{C}$ for $2 \mathrm{~h}$. Digests were extracted with phenol: chloroform:isoamyl alcohol (25:24:1) and DNA recovered by ethanol precipitation was dried and resuspended in Tris-EDTA buffer.

In the first step of PCR, 7.5 $\mathrm{\mu l}$ PCR PreMix and $0.5 \mu \mathrm{l}$ of $2 \mathrm{U}^{-1}$ IQzyme DNA polymerase were added into each $0.2 \mathrm{ml}$ reaction tube followed by $2 \mu \mathrm{l}$ of each DNA sample. Primer details and sequences are given in Lo et al. (1996) and Yoganandhan et al. (2003). The thermal cycling conditions were $42^{\circ} \mathrm{C}$ for $30 \mathrm{~min}, 94^{\circ} \mathrm{C}$ for $2 \mathrm{~min}, 15$ cycles of $94^{\circ} \mathrm{C}$ for $20 \mathrm{~s}$, $62^{\circ} \mathrm{C}$ for $20 \mathrm{~s}$ and $72^{\circ} \mathrm{C}$ for $30 \mathrm{~s}$, followed by $72^{\circ} \mathrm{C}$ for $30 \mathrm{~s}$ and $20^{\circ} \mathrm{C}$ for $30 \mathrm{~s}$. Following this PCR, $15 \mu \mathrm{l}$ nested PCR reagent mixture was added to each tube and this mixture was incubated for 30 cycles of $94^{\circ} \mathrm{C}$ for $20 \mathrm{~s}, 62^{\circ} \mathrm{C}$ for $20 \mathrm{~s}$ and $72^{\circ} \mathrm{C}$ for $30 \mathrm{~s}$, followed by $72^{\circ} \mathrm{C}$ for $30 \mathrm{~s}$ and $20^{\circ} \mathrm{C}$ for $30 \mathrm{~s}$. After addition of $5 \mu \mathrm{l}$ $6 \times$ Loading Dye, PCR aliquots were analyzed by electrophoresis in $2 \%$ agarose gels containing ethidium bromide to visualize DNA bands using a UV transilluminator. WSSV DNA amounts in each PL from each group were categorized as high (2000 DNA copies), moderate (200 DNA copies) and low (20 DNA copies) based on the detection of DNA bands of 910, 550 and $296 \mathrm{bp}$ in size, respectively. Amplification of shrimp actin gene DNA (848 bp) by the IQ $2000^{\mathrm{TM}}$ WSSV Detection and Prevention System (GeneReach Biotechnology) confirmed that each PCR performed as expected.

\section{Statistical analysis}

Data were expressed as mean \pm SD and analyzed by using 2-way ANOVA and Student's $t$-test at a $5 \%$ significant level. A multiple comparison Tukey test was performed to determine the significance of differences among parameters assessed by using the Statistica 6.0 software (Statsoft).

\section{RESULTS}

\section{Sodium alginate extraction yields and physicochemical properties}

The yields of sodium alginate from 5 separate extractions of Sargassum wightii seaweed ranged between 14.6 and $18.1 \%$, with a mean \pm SD of $16.4 \pm$ $1.4 \%$.

The sodium alginate extracts were whitish-yellow in colour and odourless, and had a salty taste and powdery appearance. A $1 \%$ sodium alginate solution had a $\mathrm{pH}$ of 9.21. Moisture contents of the 5 sodium alginate extracts were $16.0 \pm 1.1 \%$, carbohydrate contents were $46.1 \pm 2.1 \%$, protein contents were $5.2 \pm 0.9 \%$, lipid contents were $4.1 \pm 0.4 \%$, fucose contents were $29.2 \pm 1.4 \%$ and sulphate contents were $14.6 \pm 0.6 \%$. Total ash, acid-insoluble ash and water-soluble ash levels were $1.92 \pm 0.05 \%, 0.13 \pm$ $0.01 \%$ and $1.04 \pm 0.04 \%$, respectively.

\section{Growth performance of Penaeus monodon postlarvae}

After $20 \mathrm{~d}$ of feeding, the growth performance (weight gain) of Penaeus monodon PL15 fed Artemia nauplii was $243.2 \mathrm{mg}$, and PL15 fed Artemia nauplii enriched with sodium alginate powder or beads showed significant $(p<0.05)$ concentrationdependent variations. From the lowest to highest concentrations of sodium alginate powder and beads 
tested, respectively, PL weight gains after feeding on Artemia nauplii enriched with $100 \mathrm{mg} \mathrm{l}^{-1}$ were $217.2 \mathrm{mg}$ and $197.2 \mathrm{mg}$, with $200 \mathrm{mg} \mathrm{l}^{-1}$ were $244.2 \mathrm{mg}$ and $209.2 \mathrm{mg}$, with $300 \mathrm{mg} \mathrm{l}^{-1}$ were $282.2 \mathrm{mg}$ and $213.2 \mathrm{mg}$, and with $400 \mathrm{mg} \mathrm{l}^{-1}$ were $270.2 \mathrm{mg}$ and $205.2 \mathrm{mg}$ (Fig. 1). Two-way ANOVA analysis showed significant variations $(p<0.05)$ in weight gains between PL groups fed either sodium alginate powder or bead-enriched Artemia nauplii, whereas no significant variation $(p>0.05)$ was evident amongst PL groups fed with the various concentrations of alginate.

\section{Specific growth rate}

The specific growth rate (SGR) was similar amongst groups of Penaeus monodon PL15 fed control Artemia nauplii (15.8\%) and nauplii enriched with any concentration of sodium alginate powder or beads (14.8 to $16.5 \%$ ) (Table 1$)$. However, $t$-test of the SGR showed significant differences $(p<0.05)$ between control PL15 and PL15 fed Artemia nauplii

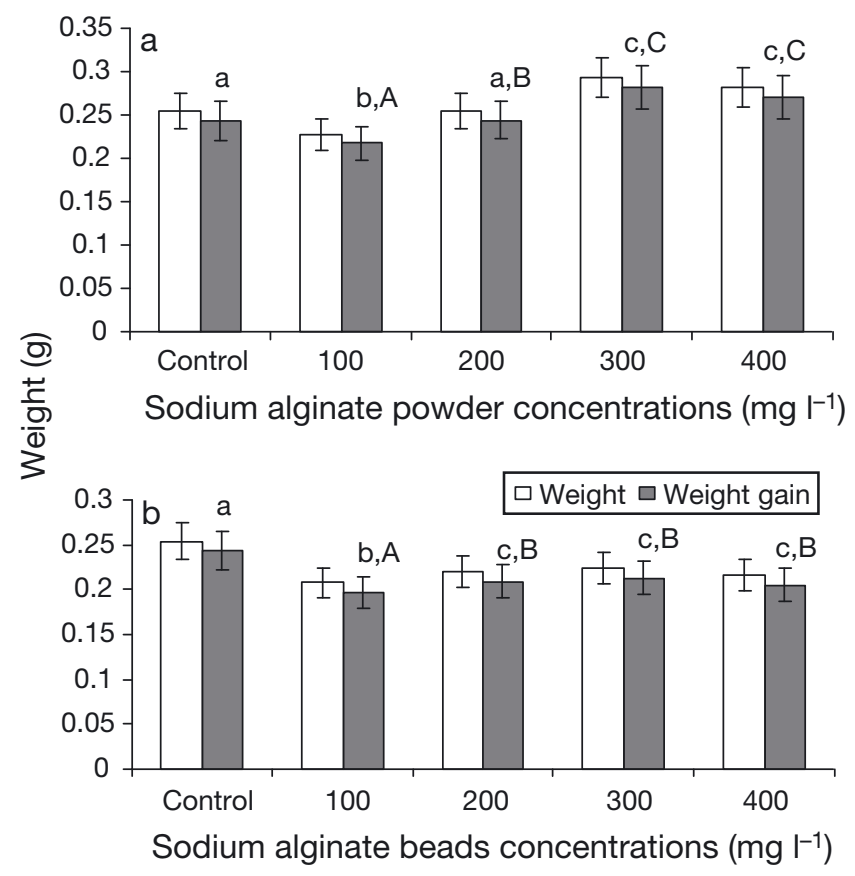

Fig. 1. Penaeus monodon. Final weight (g) and weight gain (g) of shrimp postlarvae (PL) fed Artemia nauplii enriched with different concentrations (100 to $400 \mathrm{mg} \mathrm{l}^{-1}$ ) of sodium alginate (a) powder or (b) beads for $20 \mathrm{~d}$ (PL15 to PL35). Each value is the mean \pm SD of 3 replicates. Within each group, bars accompanied by different letters are statistically different from the control (lower-case, $t$-test, $\mathrm{p}<0.05$ ) and each other (upper-case, post hoc Tukey test).
Table 1. Penaeus monodon. Specific growth rate (SGR) of postlarvae (PL) fed on Artemia nauplii enriched with different concentrations of sodium alginate powder or beads for $20 \mathrm{~d}$ (PL15 to PL35). Each value is the mean \pm SD of 3 replicates. Within each group, values followed by different superscript letters indicate significant differences from the common control (lower-case, $t$-test, $\mathrm{p}<0.05$ ), and each other (uppercase, post hoc Tukey test); the 'Beads' group is distinct from the 'Powder' group and is designated as such by ' 1 ' following the letter

\begin{tabular}{|lc|}
\hline Concentration $\left(\mathrm{mg} \mathrm{l}^{-1}\right)$ & SGR $(\%)$ \\
\hline 0 (control) & $15.8 \pm 0.9^{\mathrm{a}, \mathrm{a} 1}$ \\
Powder & $15.2 \pm 1.4^{\mathrm{a}, \mathrm{A}}$ \\
100 & $15.8 \pm 0.9^{\mathrm{a}, \mathrm{A}}$ \\
200 & $16.5 \pm 0.8^{\mathrm{a}, \mathrm{B}}$ \\
300 & $16.3 \pm 0.6^{\mathrm{a}, \mathrm{B}}$ \\
400 & \\
Beads & $14.8 \pm 0.7^{\mathrm{b} 1, \mathrm{~A} 1}$ \\
100 & $15.1 \pm 1.2^{\mathrm{a} 1, \mathrm{~A} 1}$ \\
200 & $15.2 \pm 1.4^{\mathrm{a}, \mathrm{A} 1}$ \\
300 & $15.0 \pm 1.4^{\mathrm{b} 1, \mathrm{~A} 1}$ \\
400 & \\
\hline
\end{tabular}

enriched with either 300 or $400 \mathrm{mg} \mathrm{l}^{-1}$ of sodium alginate powder or beads.

\section{Mortality following WSSV challenge}

WSSV challenge of Penaeus monodon PL35 fed control Artemia nauplii resulted in deaths from Day 3 post-challenge (pc); $50 \%$ cumulative mortality was reached on Day $6 \mathrm{pc}$ and all shrimp had died by Day 9 pc (Fig. 2). Amongst P. monodon PL35 fed Artemia nauplii enriched with various concentrations of sodium alginate powder or beads, onset of mortality was delayed to Days 4 to 6 pc and $50 \%$ cumulative mortality was delayed to Days 12 to 17 pc. On Day 21 pc when the bioassay was terminated, 0, 9, 16 and $25 \%$ of the PL remained alive in the groups fed Artemia nauplii enriched with either 100, 200, 300 or $400 \mathrm{mg} \mathrm{l}^{-1}$ of sodium alginate powder, respectively, and 2, 14, 23 and $32 \%$ remained alive of those fed with Artemia enriched with 100, 200, 300 and $400 \mathrm{mg} \mathrm{l}^{-1}$ sodium alginate as beads, respectively. The CMI of the control group was 21537; it was considerably reduced in different concentrations of tested sodium alginate powder (by 26.5 to $52.4 \%$ ) and beads (by 35.2 to $58.4 \%$ ). When compared with the control group, the reduction in mortality rates for increasing concentrations of either sodium alginate powder or beads were statistically significant $(\mathrm{p}<$ 0.05) (Table 2). 


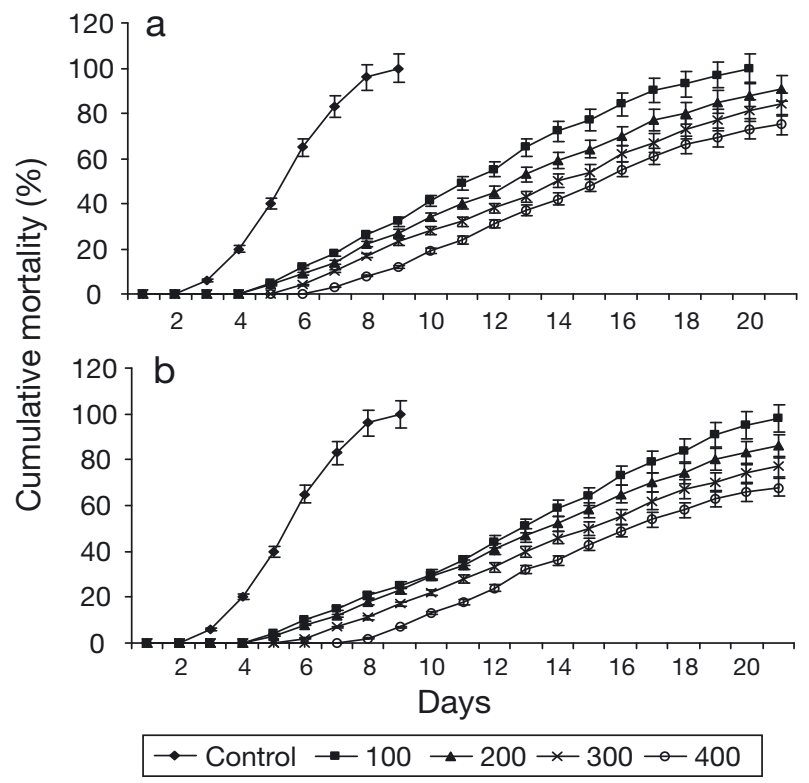

Fig. 2. Penaeus monodon. Percent (\%) cumulative mortality over $21 \mathrm{~d}$ of shrimp postlarvae fed Artemia nauplii enriched with different concentrations (100 to $400 \mathrm{mg} \mathrm{l}^{-1}$ ) of sodium alginate (a) powder or (b) beads after bath challenge with WSSV

Table 2. Penaeus monodon. Cumulative mortality index (CMI) and reduction in mortality (\%) of shrimp postlarvae fed on Artemia nauplii enriched with different concentrations of sodium alginate powder or beads after challenge with WSSV. Each value is the mean \pm SD of 3 replicates. Within each group, values followed by different letters are significantly different from the common control ( $t$-test, $\mathrm{p}<$ 0.05, and subsequent post hoc Tukey test); the 'Beads' group is distinct from the 'Powder' group and is designated as such by ' 1 ' following the letter

\begin{tabular}{|lcc|}
\hline $\begin{array}{l}\text { Concentration } \\
\left(\mathrm{mg} \mathrm{l}^{-1}\right)\end{array}$ & CMI & $\begin{array}{c}\text { Reduction in } \\
\text { mortality }(\%)\end{array}$ \\
\hline 0 (control) & $21537 \pm 244.9^{\mathrm{a}, \mathrm{a} 1}$ & $0 \pm 0$ \\
Powder & $15827 \pm 204.4^{\mathrm{b}}$ & $26.5 \pm 0.11$ \\
100 & $13541 \pm 170.6^{\mathrm{c}}$ & $37.1 \pm 0.10$ \\
200 & $11886 \pm 163.3^{\mathrm{d}}$ & $44.8 \pm 0.13$ \\
300 & $10259 \pm 122.5^{\mathrm{e}}$ & $52.4 \pm 0.03$ \\
400 & & \\
Beads & $13961 \pm 146.9^{\mathrm{b} 1}$ & $35.2 \pm 0.05$ \\
100 & $12411 \pm 138.8^{\mathrm{c} 1}$ & $42.4 \pm 0.01$ \\
200 & $10707 \pm 122.5^{\mathrm{d} 1}$ & $50.3 \pm 0.00$ \\
300 & $8951 \pm 97.9^{\mathrm{e} 1}$ & $58.4 \pm 0.02$ \\
400 & & \\
\hline
\end{tabular}

\section{WSSV infection loads detected by PCR analysis}

WSSV loads in challenged groups of Penaeus monodon PL were assessed by IQ2000 PCR analysis (Table 3, Fig. 3). Amplification of a 910 bp
Table 3. Penaeus monodon. Result of PCR analysis (see 'Materials and methods: WSSV PCR') on the range of infectivity of WSSV in control and experimental shrimps fed on Artemia nauplii enriched with different concentrations of sodium alginate powder or beads. Severe: $910 \mathrm{bp}$; Moderate: 550 bp; Slight: 296 bp

\begin{tabular}{|lcc|}
\hline $\begin{array}{l}\text { Concentration } \\
\left(\mathrm{mg} \mathrm{l}^{-1}\right)\end{array}$ & WSSV & $\begin{array}{r}\text { PCR result } \\
\text { Infectivity range }\end{array}$ \\
\cline { 2 - 3 } WSSV inoculum & +++ & Severe \\
Positive control & +++ & Severe \\
Powder & +++ & Severe \\
100 & ++ & Moderate \\
200 & + & Slight \\
300 & + & Slight \\
400 & & \\
Beads & +++ & Severe \\
100 & ++ & Moderate \\
200 & + & Slight \\
300 & + & Slight \\
400 & &
\end{tabular}

product from DNA extracted from the WSSV inoculum confirmed the presence of high WSSV genomic DNA copy numbers. A 910 bp product was also amplified from challenged PL fed control Artemia nauplii. Amongst PL groups fed Artemia enriched with $100 \mathrm{mg} \mathrm{l}^{-1}$ sodium alginate powder or beads, a 910 bp product was also amplified, but only a $550 \mathrm{bp}$ product and a $296 \mathrm{bp}$ product were amplified primarily from PL fed Artemia enriched with moderate (200 $\mathrm{mg} \mathrm{l}^{-1}$ ) and higher (300 or $400 \mathrm{mg} \mathrm{l}^{-1}$ ) concentrations of sodium alginate powder or beads, respectively.

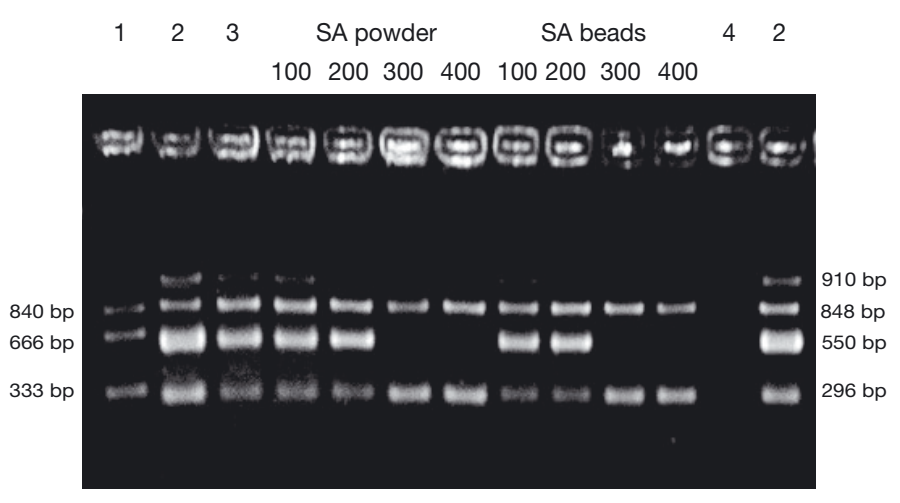

Fig. 3. Penaeus monodon. PCR analysis of WSSV infected control and experimental groups of shrimp postlarvae (PL). WSSV infectivity range: Severe: 910 bp; Moderate: $550 \mathrm{bp}$; Slight: 296 bp. Lane 1: marker; Lane 2: WSSV inoculum (from shrimp homogenate); Lane 3: positive control; Lanes 100 to 400: PL fed Artemia nauplii enriched with sodium alginate (SA) powder or beads at different concentrations

(100 to $400 \mathrm{mg} \mathrm{l}^{-1}$ ); Lane 4: negative control 


\section{DISCUSSION}

Disease caused by WSSV remains a major threat to the shrimp aquaculture industry (Wyban \& Sweeney 1991, Wilkenfeld 1992), even though recombinant proteins, dsRNA-based RNA interference and other sophisticated approaches have shown promise in limiting its impact (Witteveldt et al. 2004, Rout et al. 2007, Sarathi et al. 2008). Dietary polysaccharides, in particular alginates (Cheng et al. 2004) and fucoidans (Chotigeat et al. 2004, Immanuel et al. 2012b) derived from seaweeds, have also shown promise in protecting shrimp from infectious diseases.

In the present study, sodium alginate polysaccharide extracted from Sargassum wightii seaweed was fed to Artemia, and these alginate-enriched Artemia were fed to Penaeus monodon PL to assess their ability to protect the shrimp from infection and mortality following emersion challenge by WSSV. The average alginate yield from 5 extractions was $16.4 \pm 1.4 \%$, which compares favourably to yields of $16.9 \%$ reported for $S$. vulgare (Torres et al. 2007) and of 21.1 to $24.5 \%$ for $S$. fluitans and 16.3 to $20.5 \%$ for S. oligocystum (Davis et al. 2004). Somewhat higher alginate yields have been reported for $S$. fluitans (45\%) and S. oligocystum (37\%) (Davis et al. 2003), and for other seaweed species quite varied yields of $3.3 \%$ for S. dentifolium, $12.4 \%$ for $S$. asperifolium and $17.7 \%$ for $S$. latifolium have been reported (Larsen et al. 2003), suggesting that both species and extraction methods influence yields.

The physical characteristics of the Sargassum wightii sodium alginate extracts, including organoleptic properties, $\mathrm{pH}$, moisture content and solubility, were generally consistent with those of highly purified algal and seaweed alginates described by Xiamen JieJing Biology Technology, Xiamen. Protein, carbohydrate, lipid, fucose, total ash, acid-insoluble ash, water-soluble ash and sulphate contents of the sodium alginate extracts were also measured. Protein content $(5.2 \%)$ was somewhat higher than low-viscosity (LV, $1.1 \%$ ) and high-viscosity (HV, $1.0 \%$ ) alginates extracted from $S$. vulgare (Torres et al. 2007), but their moisture (14 and 16\%) and total ash contents ( 2 and $1 \%$ ) were comparable with the moisture $(16 \%)$ and total ash $(1.9 \%)$ contents of alginate powder prepared here from $S$. wightii, respectively. With regard to total carbohydrate $(46.1 \%)$ and fucose $(29.2 \%)$ contents determined for the $S$. wightii alginate, these varied considerably from those identified in alginates extracted from various algae harvested from the Egyptian Red Sea coast including Cystoseira trinode (74.9 and $11.6 \%$, respectively),
S. dentifolium (57.9 and 5.6\%), S. asperifolium (32.2 and $4.2 \%$ ) and S. latifolium (42.3 and $8.2 \%$ ) (Larsen et al. 2003). The variations in biochemical compositions of seaweed polysaccharides mainly depend on the seaweed species, anatomical regions, growth conditions, extraction procedures and analytical methods (Immanuel et al. 2012b).

Over a $20 \mathrm{~d}$ feeding trial, the SGRs of PL15 Penaeus monodon fed Artemia nauplii enriched with Sargassum wightii alginate powder or beads supplied to the Artemia at concentrations between 100 and $400 \mathrm{mg}$ $\mathrm{l}^{-1}$ ranged between 15.2 and $16.5 \%$ for powder and 14.8 and $15.2 \%$ for beads. In feeding trials using Artemia fed various concentrations of hot water extracts of $S$. wightii or $S$. duplicatum seaweeds, growth performance of $P$. monodon PL15 was higher (294 and $323 \mathrm{mg}$ weight gain and 16.6 and $17.1 \%$ SGR, respectively) when Artemia had been fed an extract concentration of $750 \mathrm{mg} \mathrm{l}^{-1}$ compared with a lower concentration of $250 \mathrm{mg} \mathrm{l}^{-1}$ (274 or $295 \mathrm{mg}$ weight gain and 16.3 or $16.6 \%$ SGR, respectively) (Immanuel et al. 2010). Consistent with this, improved growth performance has been noted in $P$. indicus juveniles fed Artemia nauplii enriched by feeding upon crude extracts of Ulva lactuca and $S$. wightii seaweeds (Immanuel et al. 2004) and in Atlantic halibut Hippoglossus hippoglosus larvae fed Artemia enriched by feeding upon alginate high in mannuronic acid (Skjermo \& Bergh 2004).

Following the emersion challenge with WSSV, Penaeus monodon (PL35) fed Artemia nauplii enriched with sodium alginate powder or beads experienced reduced mortality rates progressively as alginate concentrations fed to the Artemia were increased from 100 to $400 \mathrm{mg} \mathrm{l}^{-1}$. Immanuel et al. (2012b) stated that the dietary administration of fucoidan of Sargassum wightii increased resistance against WSSV in P. monodon, and observed that the percent mortality of experimental groups (0.1 to $0.3 \%$ concentration of fucoidan) of shrimp was reduced by 50.81 to $68.06 \%$ over the control group. Immanuel et al. (2010) also reported the effect of hot water extracts of $S$. wightii and $S$. duplicatum on the reduction in mortality in $P$. monodon PL against WSSV. They pointed out that the lower concentration $\left(250 \mathrm{mg} \mathrm{l}^{-1}\right)$ of both seaweed extracts showed lower (16.12 and $39.35 \%$ ) inhibitory activity against WSSV, although at the highest tested concentration $(750 \mathrm{mg}$ $1^{-1}$ ), both seaweed extracts showed higher (47.92 and $65.83 \%$ ) inhibitory activity against WSSV. Enhanced resilience against WSSV has also been reported for P. monodon PL and juveniles fed on diets containing ß-1,3-glucan (Chang et al. 1999, 2003) and for 
P. monodon fed diets containing either fucoidan extracted from the brown algae $S$. polycystum (Chotigeat et al. 2004) or a $2 \%$ extract of Cynodon dactylon, a medicinal herb (Balasubramanian et al. 2007, 2008).

Nested PCR analysis showed that WSSV loads in Penaeus monodon PL fed Artemia nauplii enriched with sodium alginate from Sargassum wightii decreased progressively as alginate concentrations fed to the Artemia were increased between 100 and $400 \mathrm{mg} \mathrm{l}^{-1}$. Such decreases have been noted similarly in P. monodon PL fed Artemia enriched with hot water extracts of $S$. wightii and $S$. duplicatum (Immanuel et al. 2010). However, in comparison with Immanuel et al.'s (2010) study, decreases in WSSV loads detected in PL fed on the sodium alginate extracted from $S$. wightii were far more uniform in the present study, suggesting that the effects of the more highly purified extract were more potent. Amongst P. monodon fed extracts of Cynodon dactylon before a WSSV challenge, decreased infection loads were detected only amongst shrimp that were fed pellets coated with the undiluted $2 \%$ extract (Balasubramanian et al. 2008).

The $\mathrm{V}_{3}$ loop motif of the WSSV gp120 envelope glycoprotein is essential for initial virus attachment to cell surface heparin sulfate before more specific binding occurs to the CD4 receptor of CD4+ cells (Witvrouw \& De Clercq 1997). The mechanism by which WSSV replication is inhibited by sodium alginate extracted from seaweed may involve binding of negatively charged sulfate groups of the polysaccharide to positively charged amino acids in this $\mathrm{V}_{3}$ loop region, thus interfering with its entry into cells. Sodium alginate enhances resistance of shrimp (Cheng et al. 2004, 2005, Liu et al. 2006) and fish (Fujiki et al. 1994, Fujiki \& Yano 1997, Cheng et al. $2007)$ to various pathogens. Moreover, alginate derived from Lessonia nigrescens fed to Litopenaeus vannamei shrimp increases prophenol oxidase activity, phagocytic activity and viral clearance (Cheng et al. 2005), and sodium alginate also enhances both the immune and antioxidant defense systems in Penaeus monodon (Liu et al. 2006). Although the data obtained here with sodium alginate extracted from the brown seaweed Sargassum wightii is promising, additional studies are required to determine whether it can be exploited as a feed additive to help protect cultured shrimp against disease caused by WSSV.

Acknowledgements. The authors thank the Department of Biotechnology, New Delhi, India, for financial support through Research Grant BT/PR15313/AAQ/03/549/2011.

\section{LITERATURE CITED}

Balasubramanian G, Sarathi M, Rajesh Kumar S, Sahul Hameed AS (2007) Screening the antiviral activity of Indian medicinal plants against white spot syndrome virus in shrimp. Aquaculture 263:15-19

Balasubramanian G, Sarathi M, Venkatesan C, Thomas J, Sahul Hameed AS (2008) Oral administration of antiviral plant extract of Cynodon dactylon on a large scale production against white spot syndrome virus (WSSV) in Penaeus monodon. Aquaculture 279:2-5

Campbell R, Adams A, Tatner MF, Chair M, Sorgeloos P (1993) Uptake of Vibrio anguillarum vaccine by Artemia salina as a potential oral delivery system to fish fry. Fish Shellfish Immunol 3:451-459

Chang CF, Su MS, Chen HY, Lo CF, Kou GH, Liao IC (1999) Effect of dietary $\beta$-1,3-glucan on resistance to white spot syndrome virus (WSSV) in postlarval and juvenile Penaeus monodon. Dis Aquat Org 36:163-168

Chang CF, Su MS, Chen HY, Liao IC (2003) Dietary $\beta-1,3-$ glucan effectively improves immunity and survival of Penaeus monodon challenged with white spot syndrome virus. Fish Shellfish Immunol 15:297-310

Chen LL, Lo CF, Chiu YL, Chang CF, Kou GH (2000) Experimental infection of white spot syndrome virus (WSSV) in benthic larvae of mud crab Scylla serrata. Dis Aquat Org 40:157-161

$>$ Cheng W, Liu CH, Yeh ST, Chen JC (2004) The immunostimulatory effect of sodium alginate on the white shrimp Litopenaeus vannamei and its resistance against Vibrio alginolyticus. Fish Shellfish Immunol 17:41-51

Cheng W, Liu CH, Kuo CM, Chen JC (2005) Dietary administration of sodium alginate enhances the immune ability of white shrimp Litopenaeus vannamei and its resistance against Vibrio alginolyticus. Fish Shellfish Immunol 18: $1-12$

> Cheng AC, Tu CW, Chen YY, Nan FH, Chen JC (2007) The immunostimulatory effects of sodium alginate and iotacarrageenan on orange-spotted grouper Epinephelus coicoides and its resistance against Vibrio alginolyticus. Fish Shellfish Immunol 22:197-205

- Chotigeat W, Tongsupa S, Supamataya K, Phongdara A (2004) Effect of fucoidan on disease resistance of black tiger shrimp. Aquaculture 233:23-30

> Chou HY, Huang CY, Wang CH, Chiang HC, Lo CF (1995) Pathogenicity of a baculovirus infection causing white spot syndrome in cultured penaeid shrimp in Taiwan. Dis Aquat Org 23:165-173

Citarasu T, Sivaram V, Immanuel G, Namita R, Murugan V (2006) Influence of selected Indian immunostimulant herbs against white spot syndrome virus (WSSV) infection in black tiger shrimp, Penaeus monodon, with reference to haematological, biochemical and immunological changes. Fish Shellfish Immunol 21:372-384

> Davis TA, Lianes F, Volesky B, Mucci A (2003) Metal selectivity of Sargassum spp. and their alginates in relation to their $\alpha$-L-guluronic acid content and conformation. Environ Sci Technol 37:261-267

> Davis TA, Ramirez M, Mucci A, Larsen B (2004) Extraction, isolation and cadmium binding of alginate from Sargassum spp. J Appl Phycol 16:275-284

> Dixon BA, Vanpucke SO, Chair M, Demasque M, Nelis HJ, Sorgeloos P, De Leenheer AP (1995) Bioencapsulation of the antibacterial drug sifrafloxacine in nauplii of the brine shrimp Artemia franciscana. J Aquat Anim Health 7:42-45 
Dodgson KS, Price RG (1962) A note on the determination of the ester sulphate content of sulphated polysaccharides. Biochem J 84:106-110

Dubois M, Gilles KA, Hamilton JK, Rebers PA, Smith F (1956) Colorimetric method for determination of sugars and related substances. Anal Chem 28:350-356

Flegel TW (1997) Major viral diseases of the black tiger prawn (Penaeus monodon) in Thailand. World J Microbiol Biotechnol 13:433-442

Folch J, Ees MI, Sloane Stanely GH (1957) A simple method for the isolation and purification of total lipids from animal tissues. J Biol Chem 226:497-509

Fujiki K, Yano T (1997) Effects of sodium alginate on the non-specific defense system of the common carp (Cyprinus carpio L.). Fish Shellfish Immunol 7:417-427

Fujiki K, Matsuyama H, Yano T (1994) Protective effect of sodium alginates against bacterial infection in common carp, Cyprinus carpio L. J Fish Dis 17:349-355

Fujiki K, Shin D, Nakao M, Yano T (1997) Effects of k-carrageenan on the non-specific defense system of carp Cyprinus carpio. Fish Sci 63:934-938

> Huynh TG, Yeh ST, Lin YC, Shyu JF, Chen LL, Chen JC (2011) White shrimp Litopenaeus vannamei immersed in seawater containing Sargassum hemiphyllum var. chinense powder and its extract showed increased immunity and resistance against Vibrio alginolyticus and white spot syndrome virus. Fish Shellfish Immunol 31:286-293

Immanuel G, Marian MP, Palavesam A (2001) Effect of feeding lipid enriched Artemia nauplii on survival, growth, tissue fatty acids and stress resistance of postlarvae Penaeus indicus. Asian Fish Sci 14:377-388

> Immanuel G, Vincybai VC, Sivaram V, Palavasem A, Marian MP (2004) Effect of butanolic extracts from terrestrial herbs and seaweeds on the survival, growth and pathogen (V. parahaemolyticus) load on shrimp Penaeus indicus juveniles. Aquaculture 236:53-65

> Immanuel G, Citarasu T, Sivaram V, Michael Babu M, Palavesam A (2007) Delivery of HUFA, probionts and biomedicine through bioencapsulated Artemia as a means to enhance the growth and survival and reduce the pathogenicity in shrimp Penaeus monodon postlarvae. Aquac Int 15:137-152

> Immanuel G, Sivagnanavelmurugan M, Balasubramanian V, Palavesam A (2010) Effect of hot water extracts of brown seaweeds Sargassum spp. on growth and resistance to WSSV in shrimp Penaeus monodon post larvae. Aquac Res 41:e545-e553

> Immanuel G, Sivagnanavelmurugan M, Palavesam A (2012a) Antibacterial effect of short-chain fatty acids on gnotobiotic Artemia franciscana nauplii against Vibrio parahaemolyticus. Aquac Res 43:518-525

Immanuel G, Sivagnanavelmurugan M, Marudhupandi T, Radhakrishnan S, Palavesam A (2012b) The effect of fucoidan from brown seaweed Sargassum wightii on WSSV resistance and immune activity in shrimp Penaeus monodon (Fab). Fish Shellfish Immunol 32:551-564

ISI (Indian Standards Institution) (1984) Handbook of food analysis, Part XIII. ISI, New Delhi

> Itami T, Asano M, Tokishige K, Kubono K and others (1998) Enhancement of disease resistance of kuruma shrimp, Penaeus japonicus, after oral administration of peptidoglycan derived from Bifidobacterium thermophilum. Aquaculture 164:277-288

Kumar PGK, Battu G, Kotha NS, Raju L (2011) Isolation and evaluation of tamarind seed polysaccharide being used as a polymer in pharmaceutical dosage forms. Res J Pharm Biol Chem Sci 2:274-290

Larsen B, Salem DMSA, Sallam MAE, Mishrikey MM, Beltagyb AI (2003) Characterization of the alginates from algae harvested at the Egyptian Red Sea coast. Carbohydr Res 338:2325-2336

Leger PH, Vanhaecke P, Sorgeloos P (1983) International study on Artemia XXIV. Cold storage of live Artemia nauplii from various geographical sources: potential and limits in aquaculture. Aquac Eng 2:69-78

Lightner DV, Hedric RP, Fryer JL, Chen SN, Liao IC, Kou GH (1987) A survey of cultured penaeid shrimp in Taiwan for viral and other important diseases. Fish Pathol 22:127-140

> Liu CH, Yeh SP, Kuo CM, Cheng WT, Chou CH (2006) The effect of sodium alginate on the immune response of tiger shrimp via dietary administration: activity and gene transcription. Fish Shellfish Immunol 21:442-452

> Lo CF, Ho CH, Peng SE, Chen CH and others (1996) White spot syndrome baculovirus (WSBV) detected in cultured and captured shrimp, crab and arthropods. Dis Aquat Org 27:215-225

> Lowry OH, Rosenbrough WJ, Fair HC, Randall RJ (1951) Protein measurement with Folin phenol reagent. J Biol Chem 193:265-275

Moscardi F (1999) Assessment of the application of baculoviruses for control of Lepidoptera. Annu Rev Entomol 44:257-289

Rahman CM, Escobedo-Bonilla M, Wille V, Alday Sanz L and others (2006) Clinical effect of cidofovir and a diet supplemented with Spirulina platensis in white spot syndrome virus infected specific pathogen-free Litopenaeus vannamei juveniles. Aquaculture 255:600-605

Rameshthangam P, Ramasamy P (2007) Antiviral activity of bis(2-methylheptyl) phthalate isolated from Pongamia pinnata leaves against White Spot Syndrome Virus of Penaeus monodon Fabricius. Virus Res 126:38-44

> Rout N, Kumar S, Jaganmohan S, Murugan V (2007) DNA vaccines encoding viral envelope proteins confer protective immunity against WSSV in black tiger shrimp. Vaccine 25:2778-2786

> Sarathi M, Simon MC, Venkatesan C, Sahul Hameed AS (2008) Oral administration of bacterially expressed VP28 dsRNA to protect shrimp, Penaeus monodon, from white spot syndrome virus. Mar Biotechnol 10:242-249

Seifter S, Dayton S, Novic B, Muntwylar E (1950) The estimation of glycon with the anthrone reagent. Arch Biochem Biophys 25:190-200

Skjermo J, Bergh G (2004) High-M alginate immunostimulation of Atlantic halibut (Hippoglossus hippoglosus L.) larvae using Artemia for delivery, increases resistance against vibriosis. Aquaculture 238:107-113

Skjermo J, Defoort T, Dehasque M, Espevik T, Olsen Y, Skjak-Braek G (1995) Immunostimulation of juvenile turbot (Scophthalmus maximus L.) using an alginate with high mannuronic acid content administered via the live food organism Artemia. Fish Shellfish Immunol 5:531-534

Song YL, Liu JJ, Chan LC, Sung HH (1997) Glucan-induced disease resistance in tiger shrimp (Penaeus monodon). In: Gudding R, Lillehaug A, Midtlyng PJ, Brown F (eds) Fish vaccinology. Karger, Basel, p 413-421

Sudheer NS, Philip R, Bright Singh IS (2011) In vivo screening of mangrove plants for anti WSSV activity in Penaeus monodon and evaluation of Ceriops tagal as a potential source of antiviral molecules. Aquaculture 311:36-41 
Takahashi Y, Uehara K, Watanabae R, Okaumura T, Yamashita T, Omura H (1998) Efficacy of oral administration of shrimp in Japan. In: Flegel TW (ed) Advances in shrimp biotechnology. National Center for Genetic Engineering and Biotechnology, Bangkok, p 171-173

Takahashi Y, Kondo M, Itami T, Honda T and others (2000) Enhancement of disease resistance against penaeid acute viremia and induction of virus-inactivating activity in haemolymph of kuruma shrimp, Penaeus japonicus, by oral administration of Pantoea agglomerans lipopolysaccharide (LPS). Fish Shellfish Immunol 10:555-558

Torres MR, Sousa APA, Silva Filho EAT, Melo DF, Feitosa JPA, Paula RCM, Lima MGS (2007) Extraction and physicochemical characterization of Sargassum vulgare from Brazil. Carbohydr Res 342:2067-2074

Tu C, Huang HT, Chuang SH, Hsu JP and others (1999) Taura syndrome in Pacific white shrimp Penaeus vannamei cultured in Taiwan. Dis Aquat Org 38:159-161

Wang YC, Chang PS (2000) Yellow head virus infection in the giant tiger prawn Penaeus monodon cultured in Taiwan. Fish Pathol 35:1-10

Watanabe T, Kitajima C, Fujita S (1983) Nutritional values of live organisms used in Japan for mass propagation of

Editorial responsibility: Jeff Cowley,

Brisbane, Queensland, Australia fish: a review. Aquaculture 34:115-143

Wilkenfeld JS (1992) Commercial hatchery status report: an industry panel view point. In: Wyban J (ed) Proceedings of the special session on shrimp farming. World Aquaculture Society, Baton Rouge, LA, p 71-86

Witteveldt J, Cifuentes CC, Vlak JM, van Hulten MC (2004) Protection of Penaeus monodon against white spot syndrome virus by oral vaccination. J Virol 78:2057-2061

Witvrouw M, De Clercq E (1997) Sulfated polysaccharides extracted from sea algae as potential antiviral drugs. Gen Pharmacol 29:497-511

Wyban JA, Sweeney JN (1991) Intensive shrimp production technology. The Oceanic Institute, Honolulu, HI

Xiang J (2001) Recent advance of research and development on marine biotechnology in China. In: Postgraduate conference on marine biology and biotechnology, 6-8 June 2001, Hong Kong. Chinese University of Hong Kong, p 12 (Abstract)

Yoganandhan K, Narayanan RB, Sahul Hameed AS (2003) Larvae and early post-larvae of Penaeus monodon (Fabricius) experimentally infected with white spot syndrome virus (WSSV) show no significant mortality. J Fish Dis 26:385-391

Submitted: July 18, 2011; Accepted: March 14, 2012 Proofs received from author(s): June 4, 2012 